\title{
PENGARUH EFEKTIVITAS TEHNIK RELAKSASI GUIDET IMAGERY TERHADAP TINGKAT KECEMASAN PASIEN PRE OPERASI DI RSUD PESANGGRAHAN JAKARTA SELATAN TAHUN 2020
}

\section{Ilham Pratama, Ayu Pratiwi}

STIKes YATSI Tangerang, Banten, Indonesia

Email: ilhamtama11@gmail.com dan ayu06pratiwi@gmail.com

\begin{tabular}{|c|c|}
\hline INFO ARTIKEL & ABSTRAK \\
\hline $\begin{array}{l}\text { Tanggal diterima: } 2 \text { Oktober } \\
2020 \\
\text { Tanggal revisi: } 10 \text { Oktober } \\
2020 \\
\text { Tanggal yang diterima: } 25 \\
\text { Oktober } 2020 \\
\text { Kata kunci: } \\
\text { Guided imagery; Pre Operasi; } \\
\text { post Operasi Operasi. }\end{array}$ & $\begin{array}{l}\text { Tujuan: untuk mengetahui pengaruh efektivitas teknik } \\
\text { relaksasi guided imagery terhadap tingkat kecemasan pasien } \\
\text { pre operasi di RSUD Pesanggrahan Jakarta Selatan tahun } \\
\text { 2020. Desain penelitian: quasi experiment menggunakan } \\
\text { rancangan One Group Pretest - Posttest. Sampel diambil } \\
\text { dengan menggunakan rumus Slovin dengan jumlah sampel } \\
\text { sebanyak } 114 \text { responden. Pengambilan sampel } \\
\text { menggunakan tehnik Purposive sampling. Penelitian ini } \\
\text { menggunakan analisis univariat dan bivariat dengan uji } \\
\text { Wilcoxon. Hasil: berdasarkan analisis univariat dari } 114 \\
\text { orang, pada pasien pre operasi yang belum diberikan teknik } \\
\text { relaksasi guided imagery mayoritas mengalami cemas berat } \\
\text { sebesar } 39,5 \% \text { ) dan yang sudah diberikan mayoritas cemas } \\
\text { ringan sebesar } 41,2 \% \text {. Berdasarkan hasil uji Wilcoxon } \\
\text { diketahuii bahwa p value 0,000 yang berarti terdapat } \\
\text { perbedaan bermakna antara kelompok pre test dan post test. } \\
\text { Kesimpulan: pasien pre operasi yang mengalami kecemasan } \\
\text { setelah diberikan teknik relaksasi guided imagery mengalami } \\
\text { penurunan tingkat kecemasan. Saran: bagi responden } \\
\text { diharapkan dapat menerapkan relaksasi guided imagery } \\
\text { sebelum dilakukannya operasi, dikarenakan sudah banyak } \\
\text { penelitian yang membuktikan bahwa relaksasi guided } \\
\text { imagery dapat menurunkan tingkat kecemasan pasien. }\end{array}$ \\
\hline
\end{tabular}

\section{Pendahuluan}

Pada masa moderenisasi saat ini, pengobatan dengan cara pembedahan banyak sekali dilakukan. Pembedahan atau operasi merupakan semua tindakan pengobatan yang menggunakan cara invasif dengan membuka atau menampilkan bagian tubuh yang akan ditangani. Pembukaan bagian tubuh pada umumnya dilakukan dengan membuka sayatan. Setelah bagian yang akan ditangani tampak, dilakukan tindakan perbaikan yang diakhiri dengan penutupan dan penjahitan luka. Operasi memiliki tiga tahapan yaitu pre operasi, intra operasi dan post operasi. Pre operasi merupakan tahapan awal dari keperawatan perioperatif. Saat menghadapi pembedahan, klien akan mengalami berbagai stressor. Pembedahan yang ditunggu pelaksanaannya akan menyebabkan rasa takut dan kecemasan pada klien yang menghubungkan pembedahan dengan rasa nyeri, kemungkinan cacat, menjadi bergantung pada orang lain dan mungkin kematian. Ketakutan dan kecemasan yang mungkin dialami pasien dapat dilihat dari tanda dan gejala seperti: meningkatnya frekuensi jantung, gerakan-gerakan tangan yang tidak terkontrol, telapak tangan yang lembab, gelisah, menanyakan pertanyaan yang sama berulang kali, susah tidur, sering berkemih (Carpenito, Vezzoli, \& Calamandrei, 2011).

Data WHO (Word Health 
Organisasion) tahun 2015 menunjukkan bahwa selama lebih dari satu abad, perawatan bedah telah menjadi komponen penting dari perawatan kesehatan di seluruh dunia. Diperkirakan setiap tahun ada 230 juta tindakan bedah dilakukan di seluruh dunia. Data Tabulasi Nasional Departemen Kesehatan Republik Indonesia Tahun 2016, menjabarkan bahwa tindakan bedah menempati urutan ke-11 dari 50 pola penyakit di Indonesia dengan persentase $12,8 \%$ dan diperkirakan $32 \%$ diantaranya merupakan bedah mayor, dan $25,1 \%$ mengalami kondisi kejiwaan serta 7\% mengalami kecemasan. Sedangkan untuk Propinsi Banten prevelensi bedah sebesar 13,7\% (Kemenkes RI, 2016).

Kecemasan (ansietas) merupakan respon individu terhadap suatu keadaan yang tidak menyenangkan dan dialami oleh semua makhluk hidup dalam kehidupan sehari-hari. Kecemasan merupakan pengalaman subjektif dari individu dan tidak dapat diobservasi secara langsung serta merupakan suatu keadaan emosi tanpa objek yang spesifik. Kecemasan pada individu dapat memberikan motivasi untuk mencapai sesuatu dan merupakan sumber penting dalam usaha memelihara keseimbangan hidup. Kecemasan terjadi sebagai akibat dari ancaman terhadap harga diri atau identitas diri yang sangat mendasar bagi keberadaan individu. Kecemasan dikomunikasikan secara interpersonal dan merupakan bagian dari kehidupan seharihari, menghasilkan peringatan yang berharga dan penting untuk upaya memelihara keseimbangan diri dan melindungi diri (Sulistyawati \& Kumalaningsih, 2012).

Kecemasan merupakan hal yang akrab dalam hidup manusia. Kecemasan bukanlah hal yang aneh karena setiap orang pasti pernah mengalami kecemasan. Kecemasan sangat berhubungan dengan perasaan tidak pasti dan ketidakberdayaan sebagai hasil penilaian terhadap suatu objek atau keadaan. Ansietas timbul sebagai respon terhadap stres, baik stres fisik dan fisiologis. Artinya, ansietas terjadi ketika seorang merasa terancam baik fisik maupun psikologis (Asmadi, 2013).

Tindakan operasi atau pembedahan merupakan pengalaman yang sulit bagi hampir semua pasien, berbagai kemungkinan buruk bisa saja terjadi yang akan membahayakan pasien. Maka tak heran jika sering kali pasien dan keluarganya menunjukkan sikap yang agak berlebihan dengan kecemasan yang mereka alami. Kecemasan yang mereka alami biasanya terkait dengan segala macam prosedur asing yang harus dijalani pasien dan juga ancaman terhadap keselamatan jiwa akibat prosedur pembedahan dan pembiusan (Depkes, 2013).

Respon kecemasan merupakan sesuatu yang sering muncul pada pasien yang akan menjalani operasi (pre operasi). Karena pre operasi merupakan pengalaman baru bagi pasien yang akan menjalani operasi. Kecemasan pasien pre operasi disebabkan oleh berbagai faktor, salah satunya adalah dari faktor pengetahuan dan sikap perawat dalam mengaplikasikan pencegahan ansietas pada pasien pre operasi di ruang rawat inap.

Kecemasan pasien pre operasi dipengaruhi oleh beberapa faktor yaitu usia, pengalaman pasien menjalani operasi, konsep diri dan peran, tingkat pendidikan, tingkat sosial ekonomi, kondisi medis, akses informasi, proses adaptasi, jenis tindakan medis dan komunikasi terapeutik (kaplan dan sudock 2014).

Kesuksesan tindakan pembedahan secara keseluruhan sangat tergantung pada fase pre operatif. Keperawatan pre operatif merupakan tahapan awal dari keperawatan perioperatif. Hal ini disebabkan fase pre operatif merupakan awal yang menjadi landasan untuk kesuksesan tahapan-tahapan 
berikutnya. Kesalahan yang dilakukan pada tahap ini akan berakibat fatal pada tahap berikutnya. Pengkajian secara integral dari fungsi pasien meliputi fungsi fisik biologis dan psikologis sangat diperlukan untuk keberhasilan dan kesuksesan suatu operasi (Mirianti, 2011).

Menurut (Mirianti, 2011), efek kecemasan pada pasien pre operasi berdampak pada jalannya operasi. Sebagai contoh, pasien dengan riwayat hipertensi jika mengalami kecemasan maka akan berdampak pada sistem kardiovaskulernya yaitu tekanan darahnya akan tinggi sehingga operasi dapat dibatalkan. Pada wanita efek kecemasan dapat mempengaruhi menstruasinya menjadi lebih banyak, itu juga memungkinkan operasi ditunda hingga pasien benar-benar siap untuk menjalani operasi.

Kecemasan pada pasien pre operasi dapat dicegah dengan menggunakan teknik relaksasi. Beberapa jenis relaksasi di antaranya adalah relaksasi imajinasi terbimbing dan relaksasi nafas dalam.

Relaksasi pernafasan adalah relaksasi dengan menggunakan nafas yang pelan, sadar dan dalam. Relaksasi meditasi (attention-focussing exerses) yaitu teknik relaksasi untuk menjernihkan pikiran dan hanyut dalam moment yang sedang berlangsung dan relaksasi perilaku merupakan psikoterapi yang didasarkan pada pengamatan, asumsi, kepercayaan dan perilaku yang mempengaruhi emosi. National Safety Council mengatakan, guided imagery adalah salah satu teknik distraksi yang dapat digunakan untuk mengurangi stres dan meningkatkan perasaan tenang dan damai serta merupakan

obat penenang untuk situasi yang sulit dalam kehidupan (Smeltzer \& Bare, 2013).
Hasil
penelitian
(Daryanti,

Widiyanto, \& Sudirman, 2020) tentang Pengaruh Terapi Guide Imagery Terhadap

Tingkat Kecemasan Pasien Pre Bedah
Operasi Mayor Di Ruang Bedah RSUD Karanganyar. Hasil penelitian menyebutkan ada pengaruh terhadap tingkat kecemasan pasien pre operasi bedah mayor diruang bedah RSUD Karanganyar. Hasil penelitian ini dibuktikan melalui uji statistik wilcoxon dimana diperoleh $p$ value 0,000 yang berarti $p$-value $<\alpha(0,05)$. Hasil penelitian ini juga selaras dengan penelitian yang dilakukan (Wijayanti \& Prasetianti, 2018) dimana ditemukan adanya pengaruh teknik relaksasi imajinasi terbimbing terhadap tingkat kecemasan pada pasien pre operasi di RSUD Patut Patuh Patju Gerung. Hasil uji statistik diperoleh $\mathrm{p}$ value 0,000 .

Berdasarkan studi awal peneliti pada bulan Januari tahun 2020 di RSUD Pesanggrahan Jakarta Selatan menunjukkan data terdapat 160 pasien operasi, yang sebagian besar 135 orang (84,4\%) mengeluh cemas menghadapi proses operasi dan mengalami peningkatan di bulan Februari menjadi 180 pasien dan yang mengalami kecemasan menjadi 157 orang (87,2\%). Berdasarkan latar belakang masalah tersebut, maka peneliti tertarik melakukan penelitian tentang pengaruh efektivitas teknik relaksasi guided imagery terhadap tingkat kecemasan pasien pre operasi di RSUD Pesanggrahan Jakarta Selatan tahun 2020.

\section{Metode Penelitian}

Design penelitian yang akan digunakan dalam penelitian ini adalah quasi experiment. Desain penelitian merupakan bentuk rancangan yang digunakan dalam melakukan prosedur penelitian. Penelitian ini menggunakan rancangan One Group Pretest - Posttest, di mana rancangan ini tidak ada kelompok pembanding (kontrol), tetapi paling tidak sudah dilakukan observasi pertama (pretest) yang memungkinkan menguji perubahanperubahan setelah adanya intervensi (perlakuan) (Notoatmodjo, 2015). 
Penelitian ini dilaksanakan di RSUD Pesanggrahan Jakarta Selatan. Penelitian dilaksanakan pada bulan April - Agustus 2020.

Populasi dalam penelitian ini adalah pasien pre operasi di RSUD Pesanggrahan Jakarta Selatan pada bulan Juni - Agustus 2020 sebanyak 160 orang. Sampel diambil dengan menggunakan rumus Slovin, dan diperoleh jumlah sebanyak 114 orang. Teknik pengambilan sampel dalam penelitian ini adalah non probability sampling dengan cara Purposive sampling yaitu unsur (anggota) populasi untuk dipilih sebagai anggota sampel. Jenis instrumen yang digunakan dalam penelitian ini adalah kuesioner pada variabewl kecemasan, sedangkan untuk teknik relaksasi guided imagery adalah sebuah intervensi.

Pengolahan data dilakukan dengan langkah-langkah sebagai berikut : (1) Editing merupakan upaya memeriksa kembali kebenaran data yang diperoleh atau dikumpulkan. Editing dapat dilakukan pada tahap pengumpulan data atau setelah data terkumpul. Peneliti mengecek kembali setiap data dan jawaban dari setiap pertanyaan pada kuesioner yang telah dikumpulkan; (2) Coding merupakan kegiatan pemberian numerik (angka) terhadap data yang terdiri atas beberapa kategori. Pemberian kode sangat penting dilakukan bila pengolahan data dan analisa data menggunakan komputer. Dalam pembuatan kode dibuat pula daftar kode dan artinya dalam suatu buku (kode book) untuk mempermudah melihat kembali lokasi dan arti suatu kode dari suatu variabel. Peneliti memberikan kode pada setiap item untuk mempermudah dalam pengolahan data yang menggunakan perangkat lunak komputer yaitu perangkat lunak; (3) Entry data adalah kegiatan memasukan data yang telah dikumpulkan ke dalam master tabel atau data base komputer dengan menggunakan program perangkat lunak, kemudian membuat distribusi frekuensi sederhana atau bisa juga dengan membuat tabel kontingensi. Peneliti memasukan setiap data ke dalam data set yaitu variabel view dan data view sebelum data tersebut diolah; (4) Entry : Pada tahap ini data yang telah ada diperiksa kembali untuk memastikan bahwa data bersih dari kesalahan. Pada penelitian ini peneliti mengkoreksi kembali data-data yang telah di entry dan mengubah setiap kesalahan atau kekeliruan yang terjadi pada saat melakukan entry data. Peneliti memeriksa kembali data yang telah di entry ke dalam komputer dengan mencocokkan data yang ada pada kuesioner; (5) Processing : Tahap ini merupakan tahap akhir dari pengolahan data, data yang sudah ada akan diproses dengan komputer. Dalam penelitian ini peneliti menggunakan dua analisis data yaitu analisis univariat dan analisis bivariat. Peneliti akan memproses kembali setiap data sesuai dengan tujuan yang diinginkan yaitu menganalisis data univariat dan bivariat.

Analisis data dalam penelitian ini dilakukan meliputi analisis univariat dan bivariat. Dengan dibantu program SPSS (Statistical Product and Service Solution) versi 21.0.

Analisis Univariat dilakukan untuk mengetahui distribusi frekuensi dan gambaran dari setiap variabel sehingga analisis berikutnya dapat berjalan lebih mudah. Dengan menggunakan rumus sebagai berikut:

$$
P=\frac{f}{n} \times 100 \%
$$

Keterangan :

$\mathrm{P}=$ Presentasi

$\mathrm{f}=$ frekuensi

$\mathrm{N}=$ responden

Analisis bivariat yang dilakukan dengan 3 langkah, yaitu : 1) uji normalitas; 2) uji t (bila berdistribusi normal dan 3) uji non paramatrik / uji wilcoxon (bila 


\begin{tabular}{|c|c|c|c|}
\hline & & f & $\%$ \\
\hline 1 & Tidak Cemas & 0 & 0 \\
\hline 2 & $\begin{array}{l}\text { Cemas } \\
\text { Ringan }\end{array}$ & 12 & 10,5 \\
\hline 3 & $\begin{array}{l}\text { Cemas } \\
\text { Sedang }\end{array}$ & 40 & 35,1 \\
\hline 4 & Cemas Berat & 45 & 39,5 \\
\hline 5 & Panik & 17 & 14,9 \\
\hline & Jumlah & 114 & 100 \\
\hline
\end{tabular}

Berdasarkan tabel 2, diketahui bahwa pada pasien pre operasi yang belum diberikan teknik relaksasi guided imagery mayoritas mengalami cemas berat sebanyak 45 orang $(39,5 \%)$, dan yang minoritas pada cemas ringan sebanyak 12 orang $(10,5 \%)$.

\section{Post Test}

Tabel 3 Distribusi Frekuensi

Tingkat Kecemasan Pasien Pre Operasi Sesudah Diberikan Teknik

Relaksasi Guided Imagery di RSUD Pesanggrahan Jakarta Selatan Tahun 2020.

\begin{tabular}{|c|c|c|c|}
\hline \multirow{2}{*}{ No } & \multirow{2}{*}{ Kecemasan } & \multicolumn{2}{|c|}{ Frekuensi } \\
\hline & & $\mathbf{F}$ & $\%$ \\
\hline 1 & Tidak Cemas & 37 & 32,5 \\
\hline 2 & $\begin{array}{l}\text { Cemas } \\
\text { Ringan } \\
\end{array}$ & 47 & 41,2 \\
\hline 3 & $\begin{array}{l}\text { Cemas } \\
\text { Sedang }\end{array}$ & 30 & 26,3 \\
\hline 4 & Cemas Berat & 0 & 0 \\
\hline 5 & Panik & 0 & 0 \\
\hline & Jumlah & 114 & 100 \\
\hline
\end{tabular}

Berdasarkan tabel 3, diketahui bahwa pada pasien pre operasi yang sudah diberikan teknik relaksasi guided imagery mayoritas mengalami cemas ringan sebanyak 47 orang $(41,2 \%)$, dan yang minoritas pada cemas sedang sebanyak 30 orang $(26,3 \%)$.
Tabel 4

Uji Normalitas

\begin{tabular}{lcrrrrr}
\hline & \multicolumn{3}{c}{$\begin{array}{c}\text { Kolmogorov- } \\
\text { Smirnov }\end{array}$} & \multicolumn{4}{c}{ Shapiro-Wilk } \\
\cline { 2 - 8 } & $\begin{array}{c}\text { Statis } \\
\text { tic }\end{array}$ & Df & Sig. & Stati & df & Sig. \\
& & & stic & & \\
\hline Pre_T & 0,226 & 11 & 0,0 & 0,87 & 11 & 0,00 \\
est & & 4 & 00 & 5 & 4 & 0 \\
Post_ & 0,214 & 11 & 0,0 & 0,80 & 11 & 0,00 \\
Test & & 4 & 00 & 6 & 4 & 0 \\
\hline
\end{tabular}

Lilliefors Significance Correction

$\mathrm{n}>50$ : Kolmogrorov-Sminov(a)

$\mathrm{n}<50$ : Shapiro-Wilk

Ho : asumsi kenormalan terpenuhi

$\mathrm{Ha}$ : asumsi kenormalan tidak terpenuhi

\section{Tabel 5}

\begin{tabular}{|c|c|c|c|c|c|c|c|c|}
\hline \multirow[b]{2}{*}{ No } & \multirow[b]{2}{*}{$\begin{array}{c}\text { Kecemas } \\
\text { an }\end{array}$} & \multicolumn{7}{|c|}{ Wilcoxon } \\
\hline & & n & Mean & SD & $\begin{array}{c}\mathrm{Mi} \\
\mathrm{n}\end{array}$ & $\begin{array}{c}\mathrm{Ma} \\
\underline{x}\end{array}$ & $\mathbf{Z}$ & Sig. \\
\hline 1 & Pre Test & $\begin{array}{c}11 \\
4 \\
\end{array}$ & 3,59 & $\begin{array}{l}0,8 \\
70 \\
\end{array}$ & 2 & 5 & - & 0,00 \\
\hline 2 & Post Test & $\begin{array}{c}11 \\
4 \\
\end{array}$ & 1,94 & $\begin{array}{r}0,7 \\
68 \\
\end{array}$ & 1 & 3 & $\begin{array}{c}9,43 \\
6\end{array}$ & 0 \\
\hline
\end{tabular}

\section{Pengaruh Efektivitas Teknik Relaksasi}

Guided Imagery Terhadap Tingkat

Kecemasan Pasien Pre Operasi Di RSUD Pesanggrahan Jakarta Selatan.

3. Analisa Bivariat

a. Normalitas

Berdasarkan tabel 4 di atas dimana sampel yang dipergunakan adalah sebanyak 114 orang maka uji yang dipakai yaitu uji Kolmogrorov-Sminov. Pada uji Kolmogrorov-Sminov dapat dilihat bahwa nilai sig. pada pada pasien pre operasi baik sebelum maupun yang sudah diberikan teknik relaksasi guided imagery lebih kecil dari 0,05 (nilai sig. < alpha) yaitu 0,000 artinya $\mathrm{H}_{0}$ gagal ditolak, maka dapat disimpulkan bahwa semua data sudah tidak 
memenuhi asumsi kenormalan atau berdistribusi tidak normal, dan uji t tidak dapat dilakukan, maka uji statistik yang dilakukan adalah uji Wilcoxon.

\section{b. Uji Wilcoxon}

Berdasarkan tabel 5.5 tentang uji Wilcoxon, dapat dilihat hasil bahwa pada pasien pre operasi yang belum diberikan teknik relaksasi guided imagery mendapat nilai mean 3.59 dengan standar deviasi 0,870 dan kecemasan minimum adalah 2 yaitu cemas ringan, serta kecemaan maksimum 5 yaitu panik.

Namun hasilnya berbeda setelah pasien pre operasi yang sudah diberikan teknik relaksasi guided imagery dengan mendapatkan nilai nilai mean 1,94 dengan standar deviasi 0,768 dan kecemasan minimum adalah 1 yaitu tidak cemas, serta kecemaan maksimum 3 yaitu cemas sedang.

Berdasarkan hasil dari perhitungan Wilcoxon Signed Rank Test, maka nilai $\mathrm{Z}$ yang didapat sebesar -9,436 dengan $p$ value (Asymp. Sig 2 tailed) sebesar 0,000 di mana kurang dari nilai $\alpha=0,05$ sehingga dapat diketahui hipotesis adalah menerima $\mathrm{H} 1$ atau yang berarti terdapat perbedaan bermakna antara kelompok pre test dan post test.

Berdasarkan hasil penelitian di atas dapat disimpulkan bahwa ada pengaruh efektivitas tehnik relaksasi guidet imagery yang signifikan sebelum dan sesudah dilakukan intervensi (teknik relaksasi guided imagery) terhadap tingkat kecemasan pada pasien pre operasi. Pengaruh efektivitas tersebut ditandai dengan adanya penurunan tingkat kecemasan setelah dilakukan teknik relaksasi guided imagery pada pasien pre oeprasi di RSUD Pesanggrahan Jakarta Selatan tahun 2020.

\section{B. Pembahasan \\ 1. Analisis Univariat}

a. Pre Test

Berdasarkan hasil
penelitian diketahui Hasil
penelitian menunjukkan
bahwa pada pasien pre operasi
yang belum diberikan teknik
relaksasi guided imagery
mayoritas mengalami cemas
berat sebanyak 45 orang (39,5\%), dan yang minoritas pada cemas ringan sebanyak 12 orang $(10,5 \%)$.

Hasil penelitian ini sesuai dengan penelitian yang dilakukan Daryanti dkk (2016) tentang Pengaruh Terapi Guide Imagery Terhadap Tingkat Kecemasan Pasien Pre Bedah Operasi Mayor Di Ruang Bedah RSUD Karanganyar. Hasil penelitian menunjukkan bahwa dari 54 orang yang diteliti sebagian besar responden mengalami kecemasan sedang sebanyak 22 responden (40,7\%), kecemasan ringan sebanyak 17 responden $(31,3 \%)$ dan kecemasan berat sebanyak 15 responden $(27,8 \%)$.

Berdasarkan hasil penelitian dari (Widyastuti, 2015) gambaran kecemasan pada pasien pre operasi 
fraktur femur di Rs Ortopedi Prof. Dr. Soeharso Surakarta responden paling banyak mengalami kecemasan sedang yaitu 21 responden dengan prosentase $65,62 \%$.

Hasil penelitian ini sesuai dengan teori (Asmadi, 2013) bahwa kecemasan sangat berhubungan dengan perasaan tidak pasti dan ketidakberdayaan sebagai hasil penilaian terhadap suatu objek atau keadaan. Ansietas timbul sebagai respon terhadap stres, baik stres fisik dan fisiologis. Artinya, Ansietas terjadi ketika seorang merasa terancam baik fisik maupun psikologis.

Hasil penelitian ini juga sesuai dengan teori Smeltzer \& Bare (2013) bahwa kecemasan (Ansietas) merupakan reaksi emosional terhadap penilaian individu yang subyektif, yang dipengaruhi oleh alam bawah sadar dan tidak diketahui secara khusus penyebabnya. Menurut peneliti banyaknya pasien pre operasi yang mengalami kecemasan hal ini dikarenakan pada pasien pre operasi kecemasan merupakan kekhawatiran yang dirasakan, kekhawatiran ini timbul karena pasien tidak mengetahui tentang konsekuensi proses operasi, dan apa saja yang akan terjadi saat operasi juga pasca operasi.

\section{b. Post Test}

$$
\text { Hasil penelitian }
$$
menunjukkan bahwa pada pasien pre operasi yang sudah diberikan teknik relaksasi guided imagery mayoritas mengalami cemas ringan sebanyak 47 orang $(41,2 \%)$, dan yang minoritas pada cemas sedang sebanyak 30 orang $(26,3 \%)$.

Hasil penelitian ini sesuai dengan penelitian yang dilakukan (Daryanti et al., 2016) tentang Pengaruh Terapi Guide Imagery Terhadap Tingkat Kecemasan Pasien Pre Bedah Operasi Mayor Di Ruang Bedah RSUD Karanganyar. Hasil penelitian menunjukkan bahwa dari 54 orang yang diteliti setelah diberikan terapi Terapi Guide Imagery mayoritas responden tidak mengalami kecemasan sebanyak 19 responden $(35,2 \%)$.

Berdasarkan hasil penelitian dari (Wijayanti \& Prasetianti, 2019) tentang penurunan kecemasan pada pasien pre operasi setelah pelaksanaan relaksasi imajinasi terbimbing di RSUD Patut Patuh Patju Gerung, menunjukkan bahwa dari 30 responden sesudah diberikan relaksasi imajinasi terbimbing paling banyak mengalami kecemasan ringan yaitu 20 responden $(66,67 \%)$.

Hasil ini menunjukkan setelah diberikan intervensi terapi guide imagery tingkat kecemasan mengalami penurunan. Hasil ini sesuai dengan teori (Videbeck, 2013) yang menyatakan bahwa 
kecemasan merupakan suat perasaan tidak nyaman sebagai ungkapan atau dread yang menunjukkan respon baik akibat stimulus internal maupun ekternal yang ditunjukkan dengan gejala fisik, emosi, kognitif dan perilaku.

Hasil penelitian ini juga sesuai dengan teori (Fortinash \& Patricia, 2012) yang menjelaskan bahwa kecemasan secara fisiologis dapat ditunjukkan dalam skala normal, meningkat, menurun atau fight or flight. Oleh karena itu, dari hal tersebut di atas dapat diketahui bahwa betapa pentingnya informasi pre operasi yang gunanya untuk mengurangi rasa cemas pada pasien.

Menurut peneliti banyaknya penurunan kecemasan setelah diberikan terapi relaksasi guided imagery, dikarenakan guided imagery telah menjadi terapi standar untuk mengurangi kecemasan dan memberikan relaksasi pada orang dewasa atau anak-anak, dapat juga untuk mengurangi nyeri kronis dan menurunkan tekanan darah. Hal ini juga sudah terbukti oleh beberapa penelitian yang sudah membuktikannya.

\section{c. Analisis Bivariat}

Hasil penelitian menunjukkan, dari Wilcoxon, dapat dilihat hasil bahwa pada pasien pre operasi yang belum diberikan teknik relaksasi guided imagery mendapat nilai mean 3.59 dengan standar deviasi 0,870 dan kecemasan minimum adalah 2 yaitu cemas ringan, serta kecemaan maksimum 5 yaitu panik.

Namun hasilnya berbeda setelah pasien pre operasi yang sudah diberikan teknik relaksasi guided imagery dengan mendapatkan nilai nilai mean 1,94 dengan standar deviasi 0,768 dan kecemasan minimum adalah 1 yaitu tidak cemas, serta kecemaan maksimum 3 yaitu cemas sedang.

Berdasarkan hasil dari perhitungan Wilcoxon Signed Rank Test, maka nilai $\mathrm{Z}$ yang didapat sebesar -9,436 dengan $\mathrm{p}$ value (Asymp. Sig 2 tailed) sebesar 0,000 di mana kurang dari nilai $\alpha=0,05$ sehingga dapat diketahui hipotesis adalah menerima $\mathrm{H} 1$ atau yang berarti terdapat perbedaan bermakna antara kelompok pre test dan post test.

Berdasarkan hasil penelitian di atas dapat disimpulkan bahwa ada pengaruh efektivitas tehnik relaksasi guidet imagery yang signifikan sebelum dan sesudah dilakukan intervensi (teknik relaksasi guided imagery) terhadap tingkat kecemasan pada pasien pre operasi. Pengaruh efektivitas tersebut ditandai dengan adanya penurunan tingkat kecemasan setelah dilakukan teknik relaksasi guided imagery pada pasien pre 
oeprasi di RSUD

Pesanggrahan Jakarta Selatan tahun 2020.

Berdasarkan hasil perbedaan tingkat kecemasan sebelum dan setelah diberikan terapi hipnosis lima jari di RSUD Pesanggrahan Jakarta Selatan diketahui bahwa sebelum diberikan terapi teknik relaksasi guided imagery mayoritas mengalami cemas berat sebanyak 45 orang $(39,5 \%)$, lalu diikuti dengan cemas sedang sebanyak 40 orang $(35,1 \%)$, dan tingkat panik sebanyak 17 orang $(14,9 \%)$, serta cemas ringan sebanyak 12 orang (10,5\%). Namun setelah diberikan terapi hipnosis lima jari diperoleh hasil mayoritas mengalami cemas ringan sebanyak 47 orang $(41,2 \%)$, lalu diikuti dengan tidak cemas sebanyak 37 orang (32,5\%), dan cemas sedang sebanyak 30 orang $(26,3 \%)$.

Hasil penelitian ini sesuai dengan teori (Potter, Perry 2011) yang menyatakan bahwa manfaat guided imagery, sebagai berikut: mengurangi stress dan kecemasan, mengurangi nyeri, mengurangi efek samping, mengurangi tekanan darah tinggi, mengurangi level gula darah (diabetes), mengurangi alergi dan gejala gangguan pernapasan, mengurangi sakit kepala, mengurangi biaya rumah sakit, meningkatkan penyembuhan luka dan tulang, untuk menciptakan gambaran yang riil berkaitan dengan kesulitan danmasalahmasalah yang mungkin akan dihadapi oleh klien, meningkatkan motivasi, memvisualisasikan atau melatih mental berkaitan dengan kegiatan yang akan dilakukan.

Teori di atas diperkuat dengan teori lain yang dikemukakan oleh (Martin, 2012) bahwa Guided imagery merupakan metode menuju rileks dengan fokus pemikiran pada imajinasi positif yang bertujuan untuk mengurangi sakit, stres, dan lain sebagainya. Dimana dalam melakukan teknik tersebut menghasilkan keadaan tenang, fokus, kesiapan energi untuk mengurangi ketidaknyamanan yang menawarkan dukungan emosional dan rasa percaya diri dalam tubuh. Guided imagery mengombinasikan implikasi verbal, teknik pernapasan, dan visualisasi untuk masuk ke alam bawah sadar. Guided imagery dapat dilakukan oleh siapa saja, karena pada dasarnya membayangkan merupakan suatu keterampilan yang dapat dilatih. Dalam latihannya, peserta harus menggunakan postur, isyarat/gerakan yang sama dalam setiap sesi sehingga terbentuk "anchor" dengan respon segera dan santai dalam postur tersebut. Imagery sering disebut dengan guided imagery, visualization, latihan mental, 
atau self hypnosis. Imagery adalah teknik yang biasa digunakan oleh psikolog olahraga untuk membantu seseorang memvisualisasikan atau melatih mental berkaitan dengan kegiatan yang akan dilakukan. Dalam konteks olahraga, imagery digunakan untuk membantu atlet membuat visualisasi yang lebih nyata berkaitan dengan pertandingan atau kompetisi yang akan dijalaninya.

Hal ini diperkuat dengan teori (Purnama, Gan, Wong, \& Lew, 2015) yang menyatakan bahwa Guided imagery merupakan salah satu metode yang dapat digunakan untuk menurunkan kecemasan dengan cara membayangkan suatu keadaan atau serangkaian pengalaman yang menyenangkan secara terbimbing dengan melibatkan indera. Beberapa istilah yang berbeda namun sejenis yang merujuk pada persiapan mental seorang atlet untuk kompetisi, selain guided imagery termasuk juga imagery, visualization, mental rehearsal, symbolicrehearsal, covert practice, imagery, and mental practice.

Hasil penelitian ini sesuai dengan penelitian yang dilakukan (Antoro \& Amatiria, 2017) tentang pengaruh tehnik relaksasi guide imagery terhadap tingkat kecemasan pasien preoperasi katarak, hasil uji paired sample ttest pada hasil skore tingkat kecemasan pada kelompok intervensi dan kontrol diperoleh nilai signifikasi $p$-value $=0,000(p$ value $<\alpha(0,05)$, maka dapat disimpulkan bahwa terdapat pengaruh teknik guided imagery dalam penurunan tingkat kecemasan pada pasien pre-operasi di RS. Permana Sari Bandar Lampung Tahun 2017.

Begitu pula dengan hasil penelitian yang dilakukan oleh (Daryanti \& Markhamah, 2016) tentang Pengaruh Terapi Guide Imagery Terhadap Tingkat Kecemasan Pasien Pre Bedah Operasi Mayor Di Ruang Bedah RSUD Karanganyar. Hasil penelitian melalui uji Wilcoxon diperoleh $\mathrm{p}$ value $0,000<0,05$. Hasil tersebut berarti ada pengaruh terhadap tingkat kecemasan pasien pre operasi bedah mayor diruang bedah RSUD Karanganyar.

Hasil penelitian ini juga sesuai dengan penelitian (Wijayanti \& Prasetianti, 2019) tentang penurunan kecemasan pada pasien pre operasi setelah pelaksanaan relaksasi imajinasi terbimbing di RSUD Patut Patuh Patju Gerung, menunjukkan hasil perhitungan dengan uji wilcoxon pada sistem komputerisasi SPSS, untuk perubahan tingkat kecemasan sebelum dan sesudah dilakukan teknik relaksasi imajinasi terbimbing dengan analisis statistik diperoleh nilai $\tilde{\mathrm{n}}=0,000$ yang artinya $\tilde{\mathrm{n}}$ $<$ á $(a ́=0,05)$, maka Ho ditolak 
dan $\mathrm{H} 1$ diterima yang berarti bahwa ada pengaruh teknik relaksasi imajinasi terbimbing terhadap tingkat kecemasan pada pasien pre operasi di RSUD Patut Patuh Patju Gerung Tahun 2018.

Berdasarkan hasil perbandingan antara tingkat kecemasan sebelum dengan sesudah diberikan terapi relaksasi guided imagery, peneliti dapat mengambil kesimpulan bahwa tingkat kecemasan dapat diturunkan melalui pemberian terapi relaksasi guided imagery. Hal ini dikarenakan kecemasan adalah respon-respon yang terkait psikologis yaitu perasaan kecewa, perasaan tak berdaya dan perasaan tidak berharga (takut ditolak). Untuk respon yang terkait dengan faktor psikomotor atau respon tubuh seperti: tidak selera makan, susah tidur, sulit dapat diatasi melalui sebuah stimulus atau terapi yang dapat diberikan salah satunya yaitu relaksasi guided imagery.

Menurut analisis peneliti tingkat kecemasan pasien pre operasi dapat diturunkan melalui pemberian terapi relaksasi guided imagery. Hal yang perlu dilakukan oleh pasien adalah dengan melaksanakan terapi relaksasi guided imagery dengan sebaik mungkin dan sikap pasien yang kooperatif. Dengan pemberian terapi relaksasi guided imagery pada pasien pre operasi, diharapkan

$$
\begin{aligned}
& \text { dapat menurunkan tingkat } \\
& \text { kecemasan pasien terhadap } \\
& \text { operasi yang dilakukan, } \\
& \text { dengan menurunkan tingkat } \\
& \text { kecemasan pasien dapat } \\
& \text { mendukung kesuksesan } \\
& \text { tindakan pembedahan yang } \\
& \text { akan dilakukan dan } \\
& \text { pengobatan pasien. }
\end{aligned}
$$

\section{BIBILIOGRAFI}

Antoro, Budi, \& Amatiria, Gustop. (2018). Pengaruh Tehnik Relaksasi Guide Imagery terhadap Tingkat Kecemasan Pasien Preoperasi Katarak. Jurnal Ilmiah Keperawatan Sai Betik, 13(2), 239-243.

Asmadi, Erwin. (2013). Pembuktian tindak pidana terorisme: analisa putusan pengadilan pada kasus perampokan Bank CIMB Niaga Medan. PT. Sofmedia.

Carpenito, Lynda Juall, Vezzoli, Fabrizio, \& Calamandrei, Carlo. (2011). Manuale tascabile delle diagnosi infermieristiche. CEA.

Daryanti, Daryanti, \& Markhamah, M. (2019). Karakter unggul dan gaya penulisan dalam Buku teks biografi indonesia bangga. Universitas Muhammadiyah Surakarta.

Daryanti, Daryanti, Widiyanto, Budi, \& Sudirman, Sudirman. (2020). Literature Review: Faktor Yang Berhubungan Dengan Rheumatoid Artritis Pada Lansia. Nursing Arts, 14(1), 7-12.

Depkes, R. I. (2013). Riset kesehatan dasar. Jakarta: Badan Penelitian Dan Pengembangan Kesehatan Kementrian Kesehatan RI.

Fortinash, K., \& Patricia, A. H. (n.d.). Worret.(2012). Psychiatric Mental Health Nursing. Philadelphia: Mosby 
Elsevier Inc.

Joudi, Marjan, Fathi, Mehdi, Harati, Hadi, Joudi, Mitra, Izanloo, Azra, Rahdari, Ali, \& Soltani, Ghasem. (2014). Evaluating the incidence of cognitive disorder following off-pump coronary artery bypasses surgery and its predisposing factors. Anesthesiology and Pain Medicine, 4(4).

Martin, Ron. (2012). Regional economic resilience, hysteresis and recessionary shocks. Journal of Economic Geography, 12(1), 1-32.

Mirianti, Dimi Pipi. (2011). Hubungan Pengetahuan dan Tingkat Kecemasan Klien Pre Operasi Katarak di Poli Klinik Mata Rumah Sakit Islam Siti Khodijah Palembang. Diakses.

Notoatmodjo, S. (2015). Promosi Kesehatan dan Perilaku Kesehatan (Cetakan V). Jakarta: Rineka Cipta.

Potter, Patricia A., Perry, Anne Griffin Ed, Hall, Amy Ed, \& Stockert, Patricia A. (2009). Fundamentals of nursing. Elsevier mosby.

Purnama, Indra, Gan, Wei Liang, Wong, De Wei, \& Lew, Wen Siang. (2015). Guided current-induced skyrmion motion in 1D potential well. Scientific Reports, 5, 10620.
Sulistyawati, Wignyanto, \& Kumalaningsih, Sri. (2012). Produksi tepung buah lindur (Bruguiera gymnorrhiza LAMK.) rendah tanin dan HCN sebagai bahan pangan alternatif. Jurnal Teknologi Pertanian, 13(3), 187-198.

Videbeck, Sheila, \& Videbeck, Sheila. (2013). Psychiatric-mental health nursing. Lippincott Williams \& Wilkins.

Widyastuti, Rany. (2015). Proses berpikir siswa dalam menyelesaikan masalah matematika berdasarkan teori Polya ditinjau dari adversity quotient tipe climber. Al-Jabar: Jurnal Pendidikan Matematika, 6(2), 183-194.

Wijayanti, G. A. Sri Puja Warnis, \& Prasetianti, Putu Ayu Suryantini. (2019). Penurunan Kecemasan Pada Pasien Pre Operasi Setelah Pelaksanaan Relaksasi Imajinasi Terbimbing di RSUD Patut Patuh Patju Gerung. Jurnal Keperawatan Terpadu (Integrated Nursing Journal), 1(2), 39-46.

\section{Copyright holder:}

Ilham Pratama, Ayu Pratiwi (2020)

First publication right:

Jurnal Health Sains

This article is licensed under: 